\title{
Hypersemiotics in Printed Commercial Advertising
}

\author{
Moh. Masrukhi \\ Arabic Literature Program, Universitas Gadjah Mada, Indonesia; \\ Email:moh_masruhi@ugm.ac.id
}

\begin{abstract}
Commercial advertising is currently created with an imaginative look. The elements are framed in verbal and nonverbal ways, and there is a structure of discourse where the message is hidden by the advertiser or copywriter. This article attempts to explore how advertisements uses verbal and nonverbal elements or signs, the relationships between these elements, and how these elements are interpreted. To understand the meaning and message of the advertisement, the elements will be analyzed with van Dijk's concepts such as macrostructures (comprehension for complex information), superstructures (the schematic form that organizes the global meaning of a text), and microstructures (text grammars), and to understand signs especially nonverbal sign the hyper-semiotics theory will be used.
\end{abstract}

Keywords: commercial advertising; verbal and nonverbal elements; signs; meaning of messages; hypersemiotic

\section{INTRODUCTION}

Commercial advertisement has currently been developing as a communication system that becomes the spearhead of marketing (marketing communication) between producers and consumers. By becoming an intermediate communication and marketing information between producers and consumers, the role of advertising is an important strategy to introduce and to explain the offered products. It acts as a way to provide information, to convince nor persuade consumers to make them interested, and then make them like, choose, and purchase the products.

Realizing the high potency in market needs, designing an advertisement has becoming a promising job as 'advertising industry' (Lee, 2011:69). The persuasive information is packaged through verbal elements and accompanied by images (nonverbal) that makes the reader interested (persuaded) (Jalal, 2006:14; Jefkins, 1994:14). The advertisements reach the consumers or distributors of speech (Rotzoll, 1996:147) can be delivered through social media, such as newspapers, magazines, billboards, and so on as these provide a wide variety of readers.
Today, the world of advertising has been advancing rapidly. Its appearance reflects the social and cultural life of the local community where the advertisements are spread. Thus, it appears there is some variation in the creation of commercial advertisements for the same goods between different kind of societies. By utilizing the social life condition of the local community, the current advertisements frequently appear attractive and convincing, thus attracting the attention of various groups. Their products are in great demand and become a representation of the increasingly rising the level of lifestyle in the world. The development of such advertising also occurred in commercial advertisements in Egyptian newspapers.

Along with the development of advertisement in the commercial advertising products of the Egyptian printed-medias (IKOMCEMES) (Masrukhi, 2016:11), there are some different phenomena that have never occurred, that is a commercial advertisement with a sign that can be considered as a hyperreality. Hyperreality is a made-up reality through signs that can become human 
imagination. The definition of hyper-imagination is also through the hyper world as it has lost connection with the reality representation (Piliang, 2003:53-54). However, the appearance of this phenomenon becomes unique and interesting to study.

Additionally, there is also the use of strange words where it does not relate with the things being discussed. However, in this relation, Gee (2005:8) states that language has meaning only in and through social practice, meaning that the linguistic forms can be functional in sociocultural practices. This can be seen as in the following warnings:

$$
\text { "التدخين لفترة طويلة يؤثر على العلاقة الزوجية" }
$$

[at-tadkhīn li fithratin thawìlatin yu'atstsiru 'alāalalāqah az-zaujiyyah]

"A long time consumption of smoking can cause interference in a marital relationship".

Figure 1. Smoking warning in Egypt

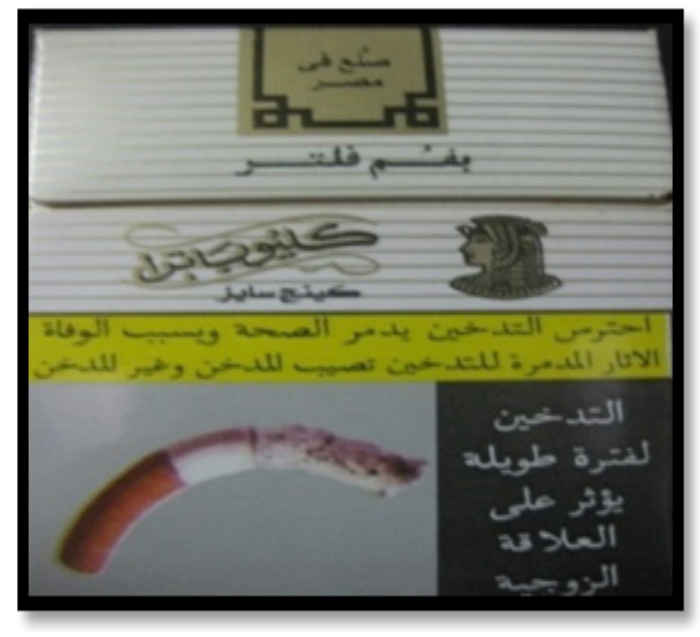

The statement in the displayed government warning for smokers in Egypt التدخين لفترة طويلة about smoking 'in long term (verbal)' is not directly related to the product of 'the crooked cigarette image (nonverbal)' Thus, it is necessary to explain the relationship and how it is intertwined, whether the used sign is the real meaning that the advertiser truly wants to deliver to prospective customers.

Based on the above description, this paper intends to reveal how product designers or copywriters utilize verbal and nonverbal elements in their advertisements, which are then linked to the socio-cultural context, particularly for commercial advertisements in Egypt printed-medias (CAEPM) that use Arabic language. In addition, this paper discusses how they can produce interpretative expressions and form a string of meanings and messages. These discussions are truly interesting idea to analyse more deeply.

Theoretically, in conversation, a person uses a sign to send the object meaning, while the other one (partner) will interpret the conveyed sign. Zoest (1993:18) says that every object which is able to be observed can be called a sign and is not limited to objects, the absence of events and structures in everyday habits can also be called a sign.

There are three signs in advertisements, namely the advertised objects (verbal or nonverbal), contexts (verbal or nonverbal), (both of which are semiotic signs), and verbal texts (which are linguistic signs). The object is the products representation of the product or service advertised. Context is an element that gives a meaning to the object being advertised. The existence of texts is to clarify and explain the meaning of the message (Piliang, 2003:263).

Signs in semiotics known as semiology, related to the definition of signs and how to apply them, how they produce meaning, and how they convey the meaning (Fiske, 2007 in Masrukhi, 2016a:48). Semiotics views communication as generating meaning in messages, both from the messenger (encoder) and the recipient of the message (decoder). In semiotics, a sign is considered to be a stimulus received by the brain to be processed, which then responder in the form of a particular reality and relationship between its users in the social life of the community (Mulyawan, 2010:13). The relationship between sign and the representation of its reality is widely known as a relationship mark between the marker (sign) and the sign (meaning). Both are not related, but are arbitrary.

Therefore, the most important point in the study of advertising is interpretation, namely the process of interpreting how verbal and nonverbal texts are signs, and how those signs are received by a person based on the vast and deep knowledge and world experience (knowledge of world), which is then utilised with the principle of analogy (Mulyana, 2015:71). This knowledge can trigger the person's memory to associate with other signs so that when experiencing something occurs, it can be digested and truly interpreted (contextual). This can be demonstrated by the words 'villa or resort' where in one's understanding, means basic 'good homes, vacation homes, usually located outside the city, in the mountain, and merely visited during holiday times (KBBI, 2013:936 
and 726). Those words are interpreted as 'comfortable', 'modern', 'expensive' and so on. Furthermore, it can also be interpreted as 'luxury', 'wealth', 'limited people', 'exclusive' and so on.

This gradual interpretation process becomes so important when understanding commercial advertising, and is called semiosis (Eco, 1992:23-24, Budiman, 1999:51, Sobur, 2003:116-117). A sign is something that represents other things (Pierce in Eco, 1979:15). The process of representing occurs when the sign is related with the one who represents.

The sign interpretation in this commercial advertisement, both verbal and nonverbal, will also be included in the study of the role of the signs whose meaning exceeds the boundaries of reality and is able to bring the realization of the hyper-reality world. Piliang (2003:53-54) refers to it as hyper-semiotic, the science of producing signs that transcend boundaries. The world of hyper-reality is the world of manipulating reality through the use of signs that become human's imagination out of their boundaries. Thus, its explanation is also through the world of hyper-reality due to the fact that it has lost contact with its real representation. McLuhan in Piliang (2003:54) says that the medium is a message. That message is conveyed through simulations and imagology and does not refer to the world of reality, such as the A Mild cigarette advertisement that shows the sport of 'wingsuit flying' (ad 2018). In the displayed advertisement the cigarette products has no relationship with that sport. In this case, Pilliang (2003:54-59) stated that the typology of the signs that become a part of the study of hypersemiotics as follows:

1. The actual signs (proper signs), means that the sign has a relatively similar or symmetrical relationship with the concept that is represented in reality. For example, red rose mark (which refers to existing interest entities) is used as a love mark and a representation of affections based on the available conventions. This sign refers to the original reality in the reflection of basic reality.

2. Fake signs (pseudo signs) are not authentic signs; they are imitated, fake, pretended, where there is no complex reduction of reality, yet there are some hidden masks of reality. For example, the image markers in Pandegelang area which was devastated by tsunami, were then used to represent the disaster in the whole area of Sunda Strait.

3. Lie signs (false signs) are signs used to cover one reality by displaying other realities with no relation to the previous one. For instance, people who wear a wig to cover their bald.
4. Recycled signs are signs used to represent reality in different context of space and time to change it into a different context. For example, the use pictures taken in certain events to mark what has happened in the past in different places as if they were the same.

5. Artificial signs are artificial and unnatural signs engineered by technology through digital technology or computers (images) and have no reference to the world of reality. In this case, the artificial sign is created not to represent other things outside of itself but to represent itself. For example, the creation of illustrations and characters in animated films (cartoons). The marks are made to show the reality in the film without taking reference from the reality world.

6. Extreme signs (superlative signs) are signs made for representing simple marks in the reality world, while in fact they appear as special marks consisting of many additional effects (audio or visual) that cause extreme (hyperbolic) impression out of its real representation. For example, fighting scenes in the films such as Transformers, Terminator, The Avengers and so on use various effects shown to surpass the real human fights.

Therefore, through semiotics and hyper-semiotics, advertising will be seen as an attempt to convey a message using a set of signs, in whatever type of signs, and in a system, advertising is need to be viewed as a unity between marks and markers consisting of verbal and nonverbal elements. There are other reinforced views, meaning that if the nonverbal signs shown in the objected advertisement are associated with other verbal signs, then it will gives the meaning or interpretation (Zoest, 1996:6). Thus, the process of interpreting verbal and nonverbal signs will lead people to understand that advertisement is an 'open text', especially on nonverbal elements, such as icons. In short, the interpretation of the commercial advertising discourse, both verbal and nonverbal texts, is the implied explanation behind what has expressed.

\section{METHODOLOGY}

Commercial advertisement is built on several supporting elements. Bathia (Mulyawan, 2010:10) states that each advertisement has four main elements, namely: (a) headline/attention-getter/caption and sub-headline, (b) body copy/main text, (c) signature line, and (d) slogan. Leech, in his book "English in Advertising" (1966:59) states that every advertisement, especially print media, 
has at least five elements; one of them is a nonverbal element. These elements are: (a) headlines, (b) body copy, (c) illustration, (d) signature line, and (e) standing details. Illustration elements (visual images) in this understanding clearly indicates that advertising consists of verbal and nonverbal elements.

Based on the advertising elements of this Leech concept, the ad data found in CAEPM conforms to the building elements grouped into types or patterns. Some data that will be used for analysis in this article is data that has been used in the articles by Masrukhi (2014, 2016a, and 2018). However, the data is used for a different perspective analysis.

The most complete ad type has five elements and the simplest ad has two elements. The types of advertisements and their supporting elements can be considered as follows.

- Advertisements for type five elements
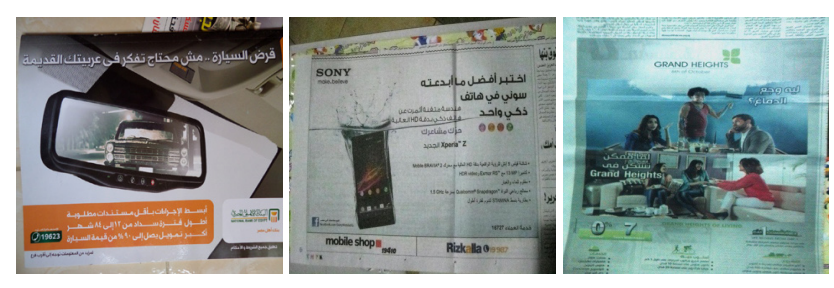

- Advertisement type four element
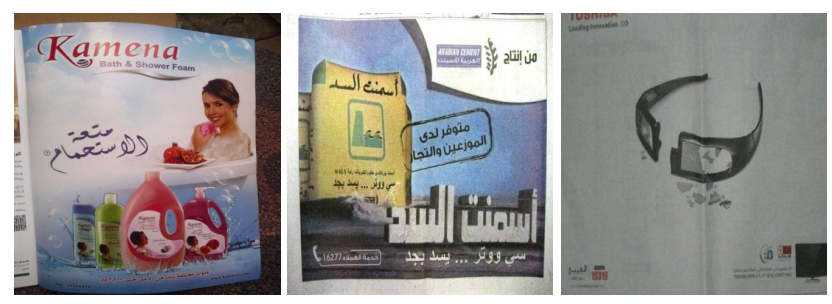

- Advertisements for type three elements
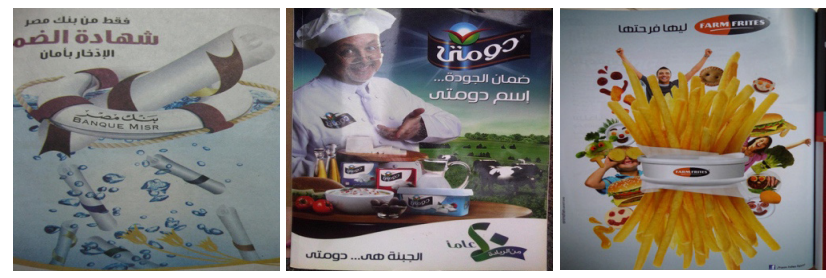

- Advertisements for type two elements
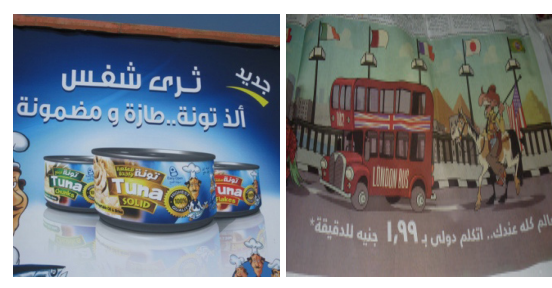

The types $(5,4,3$, and 2$)$ above, all has a variety of construction or composition of forming elements that vary from one to another (Masrukhi, 2016a:256). For example, type (5 elements) variation in composition: 1 . (KR), (NI), (Tsh), (KT), and (Kht); 2. (KR), (Tsh), (KT), (NI), and (Kht); type (4 elements) variation composition: 1. (KR), (Tsh), (KT), and (Kht); 2. (KT), (Tsh), (NI), and (Kht). However, despite the varying constructions, according to Leech, the headlines and signature lines can be considered as the most independent part of a press advertisement network, even though these are sometimes collapsed into a single display line, while others are optional and can be removed as needed.

Communication through commercial advertising consisting of elements and divided into these elements, then forms a unified flow of meaning called discourse. Discourse is a concept or idea that is packed with language, both verbal and nonverbal. To understand the dynamics of discourse, we must understand that various ideas are often packaged in the same language. The public must also be aware when interpreting that discourse also has a different perspective.

The CAEPM discourse analysis will basically interpret and explain the intentions of advertisers. Wijana (2002: 62) added that discourse analysis cannot be accomplished solely by relying on a formal approach and ignoring situational factors. The mandate of a discourse in linguistics is very dependent on the conditions of the environment or context, both linguistic context and nonlinguistic context. For this reason, commercial advertising was analyzed in few stages using the structure of van Dijk's idea of discourse (1980). There are three main structures below:

1. Micro structure

Microstructure analysis is basically text analysis (discourse) based on the intrinsic elements which include semantics, syntax, stylistics, and rhetoric or language style (1980: 29).

2. Macro structure

Macro structure is a global or general meaning of a text that is combined with another (1980: 5).

\section{Superstructure}

Superstructure is the basic framework of a text which includes the arrangement or set of elements that form a coherent unity of form (1980: 108).

The use of Dijk discourse structure concept to interpret the CAEPM data is assumed by the author that the discourse is a scheme or plot like a building. The building consists of various elements in the form of verbal texts and nonverbal texts, there are opening, contents, and 
closing. Everything is arranged in such a way as to form a solid and interesting building of advertising discourse.

Furthermore, in the discussion or analysis this paper uses the semiotic method and descriptive method. Interpretative semiotic method is a method of qualitativeinterpretative, it is the method focused on sign and text as the object of study and how researchers understand and interpret the code (decoding) behind the text and other signs on the object of research. Analysis of signs in groups or their combinations is called textual analysis. This semiotic sign not only analyse the text individually, but also includes the selection of signs that combine into larger groups of text. It also includes a representation of attitudes, ideologies, or certain myths that underlie the combination of the signs (Piliang, 2003: 270-271). Furthermore, the descriptive method is used to describe, depict, and explain the phenomenon of objects, namely CAEPM that speaking in Arabic language.

This paper is a development of previous Arabiclanguage research on CAEPM. The author's hope is that this paper can also contribute positively to other linguistic studies, especially data-based research in the form of language signs and other languages, such as verbal signs (text) and nonverbal signs (images) on these kinds of commercial advertisements.

\section{FINDING AND DISCUSSION}

As mentioned above, advertising is a persuasive marketing tool for the purpose of convincing potential customers to buy and want to use their products. In order to make this information become interesting (persuasive), the advertisement is packaged through text (verbal) (Jalal, 2006: 14) accompanied by images (nonverbal) (Crystal, 1987: 390; Jefkins, 1994: 14), and those are a discourse that must thoroughly described. Examples of these ads can be shown as follows.

\section{CAEPM analysis (type of five elements)}

To understand the advertisement discourse through the concept of hyper-semiotics and the representation of the structure of formed advertisement, in this discussion the implementation of CAEPM discourse elements will explained that advertising is formed in 5 elements (complete) and in 4 elements. The data in the discussion is shown by the advertisement, which is then explained according to the elements that form it. Data analysis will be carried out simultaneously on the supporting elements of the advertising discourse and at the same time will show the meaning and message of the advertisement.
Figure 2. Promo Advertisement

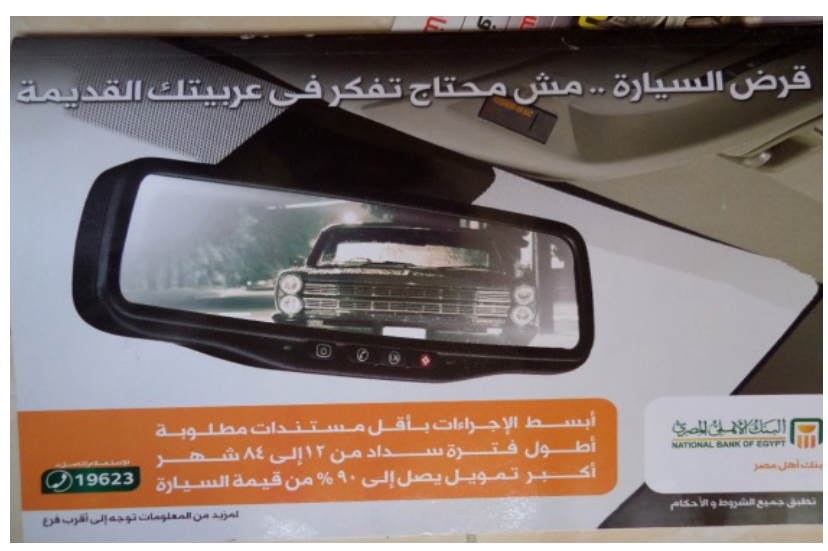

The advertisement (figure 2) above $i$ lanuttarwijiy 'promo advertisements', is the promotion product of financial services provided by National Bank of Egypt (NBE) for their customers. The provided services are loans for purchasing new cars. It consists of verbal and nonverbal elements. These advertising elements can be shown as follows.

1.قرض السيارة .. مش محتاج تفكرفعربيتك القديمة" 1ر

['ardhas-sayyārat ... misymichtāgtifakkarfì 'arabiyyatak al-'adimah]

'Car loans (new and luxurious) ... no need to think of your precious old cars'

2.

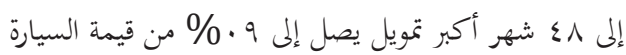

[absatu al-ijra'āt bi aqal mustandāt mathlūbah athwalu fithrati saddādin min Itsna 'asyr ilā arba 'wa tsamanīn syahr, akbaru tamwil yashil ilā 90\% min qīmat as-sayārah]

'A simple procedure with minimum documentation required, instalment period of 12-84 months, financing up to $90 \%$ of the car price'.

3نك أهل مصر

[Bank Ahli Mashr]

'National Bank of Egypt'

4. تطبيق جميع الشروط والأحكام

[tathbīq gamī asy-syurūth wa al-achkām]

'Term and conditions apply' 
5. للإِ ستعلام اتصل ب19623

\section{[lilisti Yàm ittashil bi 19623]}

'For confirmation please contact 19623'

6. لمزيد من المعلومات توجه إلى أقرب فرع

[Limazìdin min al-ma 'lūmāt tuwaggih ilā aqrab far']

'For further information please visit the nearest branch'

While the nonverbal elements are in the form of illustrations or pictures:

7. The cabin of a spacious car,

8. Trinkets and sun-proofed on the roof, and

9. Rear-view mirror inside

10. Illustration of an old car that looks dirty,

11. The surround parking car.

If we consider the 11 elements points above, the realization of CAEPM communication consists of text and context. We will use the text here as a technical terminology to refer the forms of verbal communication while context is an expression of communication that is displayed through images (Wijana, 1996: 11). This expression is out of the text, but it plays as a text-maker.

The series of texts and the context above has a different role for each of them, it can be as (1) AlKhaththur-Raisi/headline, (2) An-Nashshul-I'lani/ bodycopy, (3) At-Tashwir/illustration/attention-getter, (4) Khaththut-Tauqi $\%$ signature line, and (5) Al-Khatimah/ standing details (Leech, 1966:59; Masrukhi, 2016: 102103).

As mentioned above, to describe and explain the CAEPM 1 above, the structure of the van Dijk model will be applied to the analysis of the following advertisements.

\section{Superstructure Analysis}

The appearance of NBE advertisements above was formed on the elements of al-Khattur Ra'isi (KR), An-Nashshul i lani (NI), at-Tashwir (Tsh), Khaththut Tauqi (KT), and Al-Khatimah (Kh). These elements can be explained as follows. First, if you pay attention to the most increasing element in advertising is Al-khaththur-Ra'îsi or the KR, in the form of nonverbal signs, which are the cabin of the car, spacious, comfortable, and impressive luxury, although only the front half of the cabin is displayed, the right side of the steering wheel and mirror or glass are used to see the situation or object behind the car as seen from the mirror. This element is then followed by sub-KR (verbal sign) at the top right, namely:

12."قرض السيارة .. مش محتاج تفكر في عربيتك القديمة"

['ardh as-sayyārat ... misy michtāg tifakkar fï 'arabiyyatak al-'adìmah]

'Car loans (new and luxurious) ... no need to think of your old cars (anymore)'

Second, At-Tashwir or illustration: inside the car are mirrors with black frames. The shape is rectangular and looks thick. It looks as though the bottom of the rearview mirror is equipped with digital buttons, as they are the latest technology tools. The buttons include the power button and telephone button. This indicates that the car is sophisticated and luxurious. From the mirror reflector, there seems to be an old car (Chevrolet or Dodge which may have been made in the 50s). The car is parked in the road side and, next to it is a black electric pole. Far behind it is also a parked car. The mirror can shows that this car has long been unused and appears to be rusty, and so on. This old car certainly has ancient technology and definitely all manual.

Third, An-nashshul-i 'lāni (NI) in this advertisement is in the bottom center with a red background. The NI element is a verbal sign or text that reads:

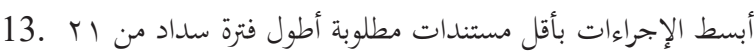

$$
\begin{aligned}
& \text { إلى 1ـ شهر أكبر تمويل يصل إلى } 9 \text { • \% من قيمة السيارة }
\end{aligned}
$$

[absatu al-ijrā'āt bi aqal mustandāt mathlūbah athwalu fithrati saddādin min itsna 'asyr ilā arba' wa tsamanīn syahr, akbaru tamwīl yashil ilā 90\% min qīmat as-sayārah]

'A simple procedure with minimum documentation required, instalment period of 12-84 months, financing up to $90 \%$ of the car price'.

Fourth, Khaththut-Tauqī'(KT) are the display of logos, brands, prices, and slogans. Because this advertisement is a promo advertisement offered by a bank, what appears in this advertisement is the Egyptian National Bank logo placed in the lower right corner and accompanied by the company name. It is the expert bank Mashr or the National Bank of Egypt.

Fifth, Khâtimah (Kh) or the closing of an advertisement accompanied by information related to a promotion held by a bank. In this ad the closing element indicates three things.

First, in the form of verbal signs connected to NI, is: 
14. للإ ستعلام اتصل ب19623

[lilisti 'ām ittashil bi 19623]

'For further confirmation please contact 19623'

This element is placed at the end of the sentence content or body of the ad (NI) in the lower left corner.

Secondly, still a verbal sign, located in the bottom right corner, is:

15. تطبيق جميع الشروط والأحكام

[tathbīq gamī 'ash-syurūth wa al-achkām]

'Terms and conditions apply (SKB)'

Third, in the form of additional information for prospective customers or consumers, is:

16. لمزيد من المعلومات توجه إلى أقرب فرع

[Limazīdin min al-ma 'ūmāt tuwaggih ilā aqrab far']

'For further information please come to the nearest branch'

Information as the closing of the promo is delivered by NBE, and then this attachment is placed in the bottom left corner in the line with the second part of the Kh element.

\section{Microstructure}

The micro structure is textual analysis. The discussion consists of two stages, namely the discussion of verbal signs and the discussion of signs, which is outside of language or nonverbal.

\section{Verbal elements}

In the Egypt National Bank promo advertising above, the verbal signs displayed as mentioned above, are $s u b$ Khaththur Ra'isi (KR) text (12), an-nashshuli lani (NI) text (13), Khaththut Tauqi' (KT), and Khatimah (Kh) in texts $(14,15$, and 16).

Lexically, the use of sentences in the NBE advertisement can be used in Arabic fush-cha (Modern Standard Arabic/MSA) and Ammiyah Arabic (Egyptian Arabic Colloquial/ECA). For example, in the text (11) the sentence 'ardh as-sayyārat' car loans '(MSA) and' ... michtāg tifakkar fì 'arabiyyatak al- 'adīmah' No need to think (old car)' is ECA. The use of a variety of ECAs in commercial advertisements shown is to make it easily understood by Egyptian societies as the Ammiyah language is widely used by the general public.
The nature of the advertising language is short and dense, but written grammatically and in accordance with its meaning, the used sentence has undergone lapse. The immersion is the form of verbal sentences or the number of fi'liyah, namely the akhadzta sentences (2nd perfectum + pronominal verb) 'You have already taken or chashalta (2nd perfectum + pronominal verb) 'You have already got'. This verbal sentence is consecutively located before the phrase ardhas-sayyärat 'car loan'. Completely, the sentence should be akhadzta/chashalta ardhas-sayyārat 'You have obtained a car loan (this luxury)'. The next step is the pronoun between anta or inta, which means 'you'. This pronominal should be located before the verbal sentence 'misy michtāg tifakkar fi 'arabiyyatak al- 'adimah' and means there is no need to think about your battered car anymore'.

In addition to lapses, in this sentence there should also be a series of two sentences. Sentences in Arabic use particle links waw 'and' which is in charge of arranging sentences/akhadzta ardh as-sayyārat/and sentences/inta misy michtāg tifakkar fì 'arabiyyatak al-'adīmah/.

Thus the overall sentence should be:

[akhadzta ardh as-sayyārat, inta misy michtāg tifakkar fì 'arabiyyatak al 'adimah]

'You already have a car loan (new and luxurious), you don't have to think of your battered car anymore'.

2. Nonverbal elements

In the banking service promo advertisement, the nonverbal sign is shown in the KR, Tsh, and KT elements. The $\mathrm{KR}$ display is a cabin icon of a car. This icon shows the condition of a new, spacious and sophisticated car. On the right roof, there are PASSENGER AIR BAG inscriptions and on the right side there are also buttons associated with the glass window on the roof of the car (sun roof) so that the glass can be opened and closed for illumination or lighting in the cabin.

$T s h$ of the rear view mirror with old car reflection inside showa cars that are shabby, neglected, and piled on the side of the road. The old car must be left there forever. It can be closely noticed based on that night atmosphere that the rear looks translucent, illuminating what is in the car and showing that the car is empty.

From the headlights on the front left, the car appears to be dirty from dust, both on the roof and on the hood of the car. On the left rear (on the left side of the road), there is also another car parked on the left side of the road. On both sides of the road are trees that look lush. All of these are a reflection that the car has been 
parked for a long time in that place.

From the iconic analysis, there appears to be a very close relationship in this advertisement. The icon of a luxury car, new and with advanced features will definitely be far more comfortable and safe, and anything can be done when driving a car including mobile phones. The presence of various buttons clearly shows that the car is the latest style and very luxurious. Thus the old car that appears in the rear view mirror ought to be abandoned and does not need to be thought about or remembered.

In addition, there is another nonverbal sign, the trusted National Bank logo in Egypt. The purchase of a new car is supported by this bank with a maximum loan. As said by the bank, the procedure to get a loan is easy and not complicated. The loan funds obtained are maximal and can be repaid in up to 84 months.

\section{Analysis of the Meaning of Advertisement Messages}

The meaning of advertising messages is the core and central meaning that cannot be separated according to the sign of the advertisement builder. The meaning gained is the overall understanding of the sign and construction along with the discourse. The goal of this message is the meaning that can be interpreted according to the references obtained from the display of advertisements.

Bank al-Ahly al Mashry or National Bank of Egypt (NBE) is the oldest bank in Egypt. The bank was established on June 25, 1898, by the government in Egypt. Currently, this bank has a few branches abroad, such as in New York, Shanghai, and the representative offices in Gulf countries, such as Dubai and countries in Africa, such as in Johannesburg, Sudan, Adis Ababa, and so on (South Africa). In 2007, the reputation of its assets reached 226th rank among the world's banks and 3rd place among Arabian banks (www.nbe.com.eg).

Like conventional banks in general, NBE also has a responsibility to provide loans to its customers with $25 \%$ of total assets, both investment loans, working capital loans and consumer loans (loan and advances). One of them is vehicle ownership loans. From the advertisement above, NBE launches consumer credit by providing car loans. The provided credit can reach $90 \%$ of the price of the car. The installments can be paid in 84 months. Please use this good opportunity. You don't have to bother with your old car anymore. With your new car using a soft loan from the National Bank of Egypt, you will feel the luxury of your new car. Your new car is equipped with the latest, sophisticated, and comfortable car features.

Such expressions are conveyed in accordance with the illustration, as if the new car owner was watching and feeling affection with the old car that was abandoned, as if the owner said "sorry ... my car, I left you there, even though I felt you were very meritorious for this, you have helped me in joy and sorrow, and so on". Feelings were left as if they were also reflected in the rearview mirror of the car, namely "me" is now an old car, dirty, weak, and helpless, a wrecked car, and useless, so "I" is left alone, alone on the roadside and so on.

On the other hand, if you look at the mirror shape and interior of the most prominent cars, you will notice that this car is different, not only with the car that is being abandoned, but also with most existing cars. On the mirror glass on the bottom side there are a series of buttons, including the power button (on/off), telephone, and two other buttons so we can conclude that the mirror also functions as a telephone, speaker, and others.

From this description it can be proven that each element and subject in this advertisement is interrelated and mutually supports the achievement of a complete and coherent development of discourse; the message is conveyed in a simple and easy way through verbal and nonverbal forms. These advertisements have meaning that can be well understood by readers or prospective consumers. This can be observed from the placement of supporting elements in this advertisement as the building of a coherent advertising discourse.

Based on the description above, hyper-semiotic marks used in this advertisement are actual marks or proper signs. The old and dusty car icon parked on the roadside is used to represent the uselessness of the car. In today's life, such car technology must have been replaced with new and modern technology. This mark is far different from what the car owner did. This mark is used for simple things. Something that is not used anymore is abandoned, is not treated anymore, and so on. Therefore, this mark representation makes reference to the reality world.

\section{CAEPM analysis (type 4 elements)}

Figure 3. TOSHIBA Ad

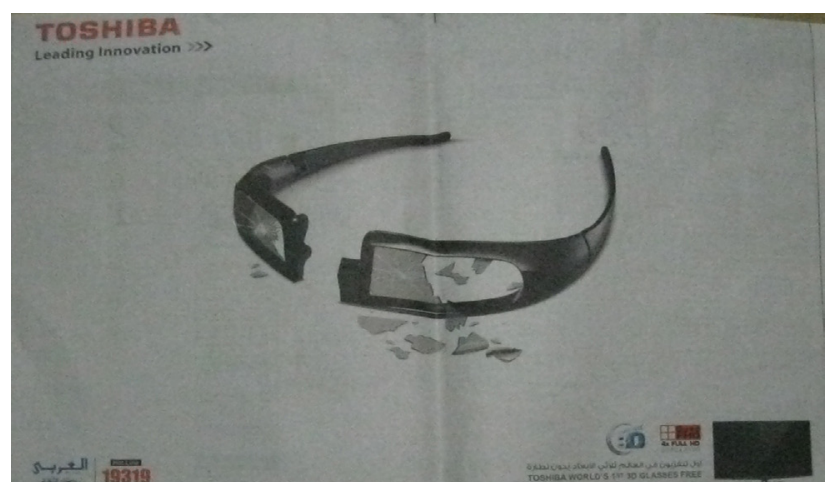


From the appearance of the advertisement above, we can see the existence of verbal and nonverbal elements. There are parts that stand out and don't stand out. The verbal element appears in the upper left corner of the text:

1. "TOSHIBA Leading Innovative $>>>$

2. 2. "أول تلفزيون في العالم ثلاثى الأبعاد بدون نظارة

[awwal tilifiziyyūn fì al 'àlam tsulātsi al-ab'ād bidūnNazhzhārah ]

[TOSHIBA WORLD'S 1 ${ }^{\text {ST }}$ 3D GLASSES FREE] 'The FGirst 3D Television in the Glasses-Free World'

3. '19319 Hotline' followed by the text:

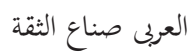

[Al- 'arabiy shuna'ats-tsiqah]

Al-'Arabi guarantee the quality' and website www. elarabygroup.com

While the nonverbal elements are:

4. Picture of the broken glasses (very prominent)

5. The image of television type in the lower right corner (not prominent)

\section{Superstructure Analysis}

The following are advertisements for electronic products Productions are produced by leading Japanese factories with the TOSHIBA brand. Through these advertisements, advertisers want to convey to customers that TOSHIBA as the leading manufacturer of innovations produces new products, namely $3 \mathrm{D}$ televisions with no glasses.

The TOSHIBA advertisement consists of four forming elements, both verbal and nonverbal. The structure is built on elements KR, Tsh, KT, and Kh. The first advertisement is for TOSHIBA products, which is also $\mathrm{KT}$, including logos and product names. The product also acts as the background of the ad. KR in this advertisement is built in the form of nonverbal elements. The form is a broken black sunglasses icon and broken glass. This KR ad also acts as Tsh. Second, in this advertisement sunglasses are shaped like spheres. The sunglasses are broken into two parts exactly in the middle. Both sides of the glasses have now broken the glass. The glass fragments still appear scattered around the eyeglass frame.

Third is KT which in this advertisement consists of three parts, which are the TOSHIBA logo and Leading Innovation slogan. Afterwards, the product slogan above is then shown through a nonverbal element in the form of a 42 inch television product icon (in the lower right). The icon is followed by the verbal sign QUAD FHD 4x Full HD 3840x2160, product specification statement, and the 3D Glass Free icon, and then followed by a verbal sign (at the bottom right) that reads:

$$
\begin{aligned}
& \text { "أول تلفزيون في العالم ثلاثى الأبعاد بدون نظارة" } \\
& \text { [awwal tilifiziyyūn fì al- ālam tsulātsi al-ab ād } \\
& \text { bidūn nazhzhārah ] }
\end{aligned}
$$

'The first 3D television with glasses-free in the world'

Fourth, is khatimah or the closing of this advertisement with statement containing the contact address or hotline 19319 , followed afterward by verbal sign Al- 'araby shuna' ats-tsiqah 'Al-'Araby quality assured' and the address in the form of a website (www. elarabygroup.com).

\section{Micro Structure Analysis}

As discussed above, textual analysis in this advertisement will be divided into two stages; the analysis of verbal signs and nonverbal sign analysis. Analysis of the verbal sign on the Toshiba advertisement above will be carried out mainly on the KT and Kh elements.

1. Analysis of verbal signs on KT

The first verbal sign on this ad KT is a logo or brand, TOSHIBA itself, and then followed by the product slogan 'Leading Innovation'. If observed carefully, both are one entity, namely TOSHIBA Leading Innovation which means TOSHIBA is a company that always leads new innovations in the electronic field. This logo and slogan is given an icon '>>>' that is printed thickly. The second verbal sign is located in the lower right, in Arabic writing that reads:

\section{'Awwal tilifiziyyūn fì al-'ālam tsulātsi al-ab 'ād bidūn nazhzhārah' \\ "The first television in the 3D world without glasses"}

If grammatically considered, the sentence above has experienced obliteration or concealment. The imposition that occurs is that the sentence subject is not clearly stated verbally, but is indicated by a nonverbal sign (on the right), which is the icon of a television with various specifications placed above the sentence (QUAD FHD 4x Full HD 3840x2160 and 3D icon Glass Free).

In advertising subject, this form is commonplace 
and it must be assumed that this sign (icon) actually refers to the certain subject. However, the language in grammar still raises questions for the reader, that is: "What is the first television in the world? There are so many television products", and so on.

In Arabic grammar, the subject of the sentence does not have to be mentioned twice, but must be replaced with dhamir 'pronouns'. This pronoun then replaces the position of the sentence subject. This pronoun must 'refer' accordingly to the subject, both in terms of form, type, and number so that the sentence becomes perfect. In accordance with what is meant in Arabic sentences subjects (mubtada') and predicates (khabar) must be the same in terms of type (mudzakkar 'male' and muu'annats 'female') and number (singular, multiple, and plural).

When viewed carefully, the sentence above is closely related or tied to the logo (in the upper left corner) and also the television icon (in the lower right corner), that is TOSHIBA. It is also shown clearly in the English sentence below:

\section{'TOSHIBA WORLD'S 1ST 3D GLASSES FREE'}

Likewise in Arabic, the subject of the sentence as above can be TOSHIBA, 4 nouns, huwa 'dia' (2nd pronoun mudzakkar 'male') or ism isyarah hadza 'this' (mudzakkar) so that the sentence becomes:

6a. /TOSHIBA awwal tilifiziyyūn fì al-`ālam tsulātsi al-ab 'ād bidūn nazhzhārah'l

'TOSHIBA is the first 3D television in the world with no glasses'

6b. /TOSHIBA huwa awwal tilifiziyyūn fì al'àlam tsulātsi al-ab 'ād bidūn nazhzhārah/

'TOSHIBA is the first 3D television in the world with no glasses'

6c. Ihuwa awwal tilifiziyyūn fì al- 'àlam tsulātsi al-ab 'ād bidūn nazhzhārah/

'He is the first 3D television in the world with no glasses'

6d. Ihadza awwal tilifiziyyūn fì al- 'àlam tsulātsi al-ab 'àd bidūn nazhzhārah/

'This is the first 3D television in the world without glasses'

Furthermore, the verbal element in khatimah contains a notification of contact details that can be contacted to obtain information needed by consumers, namely Al-'Arabyshuna'uats-tsiqah hotline 19319 and the website address that can be visited (www. alarabygruop.com).

2. Nonverbal elemental analysis

In TOSHIBA's advertisements nonverbal elements are displayed in four elements, namely al-Khaththur Ra'isi, at-Tashwir, Khaththut Tauqi', and Khatimah. This advertisement is in the form of the sunglasses icon in an upside down position. These glasses are curved in the shape of a face and are trendy. This type of eyewear is the favored model by today's young generation.

At-Tashwir or this advertising illustration is a nonverbal or visual sign of sunglasses that has broken in the middle into two parts; the glass is broken and scattered around the glasses. Some of the glass is attached to each frame, but it also has cracked and formed an appearance similar to a spider's nest. Secondly, the television icon is located in the lower right corner. This icon is accompanied by a spectacle that is a feature of this $3 \mathrm{D}$ television.

\section{Macro structure analysis}

In this stage of analysis the advertisers want to convey their meaning and message in advertisements. Analysis is accomplished through a contextual approach supported by previous textual analysis.

\section{Analysis of the Meaning of Advertisement Messages}

As seen on the screening of 3-dimensional films played in theatres, the audiences are frequently given additional equipment, which in this context is $3 \mathrm{D}$ glasses. The glasses must be worn by the audience when the film has started playing. These glasses are made specifically to obtain special effects that can only be seen by the audience using these glasses so that the viewer will feel really involved and participate in experiencing the events.

The display of this advertisement is also centered on the KR and Tsh elements located in the center of the frame of advertisement, which is the broken and scattered sunglasses. The appearance of the broken glasses is used as a KR element as well as Tsh. The placement of KR in this advertisement is also in a very strategic position, as an eye catcher or attention gainer, right in the middle of the ad frame. With this template, the advertisers want to convey their meaning and message firmly on the existence of many 3D movie products. If you want to watch 3-dimensional (3D) movies you don't need to go to the movies anymore and you don't need to use glasses.

$3 \mathrm{D}$ movies on the screen are now anticipated by 
TOSHIBA with its new product, 3D television. With the creation of the new 3D television technology, 3D glasses are no longer needs, items that are not needed are junk, useless items, discarded items, and so on. Similarly, the glass had broken so it was a junk. Thus, now without 3D glasses you can still watch 3D movies through your own television at home. 3D television is now manufactured by a Japanese company 'TOSHIBA', so you can simply buy this TV at a nearby distributor, such as in Al- 'Arabi (Kht). The production of 3D television is developed by technological advancements pioneered by Toshiba with syi'ar or slogan 'Leading Innovation' which are always included in its advertisements as the pioneer of innovation.

From this explanation, it is shown that the state $(\mathrm{KR})$ is an evidence of its association with the verbal element in KT under the bidūni nazhzhārah 'without using glasses'. The connection also appears with the product logo and producer slogan in the verbal form "TOSHIBA Leading Innovation". The leading innovation phrase indicates that manufacturers have made new devices that have not been made by other electronic manufacturers. This company innovation not only creates $3 \mathrm{D}$ television, but to make people enjoy 3-dimensional films with no longer bothered by wearing glasses such as watching 3D movies in the old cinemas. Therefore, Toshiba, which is well-known for its product innovations, with its experience, and innovations that are always carried out continuously succeed in creating 3-dimensional television, and without using glasses. Thus, the current 3-dimensional films can not only be enjoyed in cinemas, but can be enjoyed through smart television and no longer need 3D glasses. Because 3D technology on television has been found, enjoying 3D movies does not require 3D glasses anymore. This means that 3-dimensional glasses can be said as out of dated (broken), so just leave it or just throw it away, such glasses are no longer needed in the present era.

The starting point of this advertisement using KT elements in Latin typography "TOSHIBA Leading Innovation" located in the upper left corner, according to the Latin character writing, from left to right. Placing this element in the upper left corner shows a very high pride and must get a balanced appreciation because it has succeeded in making actual and unprecedented innovations. This KT element then leads to the KR element placed right in the middle of the ad so that this element becomes the central point of view or attention getter (Tsh). With this position, from any angle the reader can see it very clearly. Element KR appears alone in the middle because there is an explanation placed in the lower right corner, namely elements (NV) and (V). Lastly, the placement of elements of KT in the form of hotline number distributors or trusted agents for a long time, namely $\mathrm{Al}$ - 'Arabi Group. This is a sign that if you need this latest Toshiba product that doesn't need to be bothered, $A l$ - 'Arabi has prepared it for you. You easily call, Al-'Arabi is ready to go to you.

The conveyed message in this advertisement is that in an advanced era of technology everything can be strived for which previously seems to be impossible, now becoming possible with technology. All of them will give result with will and hard work to make innovations. In this case, TOSHIBA has accomplished them and has always pioneered this kind of technological innovation. It is purposed for providing satisfaction and comforting human life, as well business. Hence, if you want to see the 3D file no need to go far to the cinema, but enough with TOSHIBA 3D television, you can enjoy it at home with the whole family.

Based on the description above, hyper-semiotic marks used in this advertisement are extreme or superlative marks and proper signs. Broken glass frames are used to represent the uselessness of the tool in viewing $3 \mathrm{D}$ movies. This tool has been replaced with a new technology, namely 3D television. This mark is a reality used for simple things. Something no more used is usually just put or stored. Generally, 3D glasses in theaters are made of plastic, not made of glass so they are not easily broken. Therefore, this mark representation does not take reference to the world of reality but is exaggerated. While the KT marks used are a proper or actual mark, it is the television icon shown is parallel or in accordance to the existing reality.

\section{CONCLUSION}

The results of the CAEPM research in relation to the meaning or message contained to be conveyed to reader can be concluded from the aspects of verbal and nonverbal meaning. The message conveyed in the CAEPM is mostly delivered through nonverbal elements because nonverbal elements are more attractive, more persuasive, easier and quickly digested by readers or prospective consumers rather than verbal elements because it is easier to remember. The appearance of nonverbal elements in advertising, on the Tsh (illustration) element is more interesting and becomes eye-catching and getting attention compared to the verbal element in the KR element (headline). In this case, the verbal element tends to be said to be an explanatory and supportive understanding of commercial advertising, entirely and 
comprehensively. This can be the reason for criticizing the previous opinion that verbal elements have a more dominant function as the eye catcher's attention / reader attention rather than nonverbal. Thus, what must be seen is that the elements and points in this advertisement are interrelated and mutually supportive in achieving a complete and coherent discourse development, messages are conveyed in a simple and easy way through verbal and nonverbal forms, and have a well understood meaning for the reader or prospective customers.

\section{REFERENCES}

Berger, Arthur Asa (2010). PengantarSemiotika: Tanda Tanda Dalam Kebudayaan Kontemporer. Yogyakarta: Penerbit Tiara Wacana.

Cook, Guy (2001). The Discourse of Advertising. Second Edition. London and New York: Routledge.

Crystal, David (1987). The Cambridge Encyclopaedia of Language. New York: Cambridge University Press.

Dahdah, Antoine (1992). Qawa id al- 'Arabiyah al'Alamiyyah. Arabic-English. Beirut: Maktabah Lubnan.

Dyer, Gillian (1989). Advertising as Communication. London and New York: Routedge.

Gully, Adrian (1997). The Discourse Of Arabic Advertising:Preliminary Investigations. Journal of Arabic and Islamic Studies, 1, 1-49.

Halliday, M.A.K. \& Ruqaiya Hasan (1992). Bahasa, Konteks, dan Teks: Aspek-aspek Bahasadalam Pandangan Semiotika Sosial. Yogyakarta: Gadjah Mada University Press.

Jalal, Aiman Sa'id (2006). Lughatu al-I'lan at-Tijariy, Dirasah lima Nasyara fi 'Amai 1952 wa 2002 fi Jaridah Akhbar al-Yaum. Cairo: Maktabah Al Adab.

Jefkins, Frank (1994). Advertising. Second Edition. London: Pitman Publishing.

Lee, Monle \& Carla Johnson (2011). Principles of Advertising: a Global Perspective. $3^{\text {rd }}$ Print. Translated by Haris Munandar and Dudy Priatna. Jakarta: Prenada.

Leech, Geofrey N. (1966). English in Advertising: A Linguistic Study of Advertising in Great Britain. First Published.London: Longman.

Masrukhi, Moh. (2014). Struktur Iklan Komersial di Media Cetak Mesir. CMES, VIII(2).

Masrukhi, Moh. (2016a). Unsur Verbal dan Nonverbal dalam Iklan Media Cetak Mesir: Analisis Wacana. Unpublished Disertation. Sekolah Pascasarjana Univesitas Gadjah Mada, Yogyakarta.

Masrukhi, Moh. (2016b). Iklan Komersial Media Cetak; Tinjauan Teks dan Konteks. CMES, IX(2).

Masrukhi, Moh. (2018). Menggagas Formulasi Baru tentang
Bahasa, Sastra, dan Budaya Arab. Yogyakarta: Idea Press.

Mulyawan, I Wayan (2010). Hipersemiotika Periklanan: Analisis Praktis. Denpasar: Udayana University Press.

Piliang, Yasraf Amir (2003). Hipersemiotika Tafsir Cultural Studies Atas Matinya Makna. Yogyakarta: Percetakan Jalasutra.

Van Dijk, Teun. A. (1980). Macrostructures An Interdisciplinary Study of Global Structures in Discourse, Interaction, and Cognition. Hillsdale, New Jersey: Lawrence Erlbaum Associates, Publishers.

Van Dijk, Teun. A. (1985). Handbook of Discourse Analysis: Discourse and Dialogue. Volume 3. Orlando: Academic Press, Inc.

Sobur, Alex (2009). AnlisisTeks Media: Suatu Pengantar untuk Anlisis Wacana, Analisis Semiotik, dan Analisis Framing. $5^{\text {th }}$ Print. Bandung: Remaja Rosdakarya.

Wijana, I Dewa Putu Wijana (1991). Language of Advertising. Laporan Penelitian. Yogyakarta: Universitas Gadjah Mada.

Zoest, Art van (1996). Peranan Konteks Kebudayan, dan Ideologi di dalam Semiotika. Dalam Serba-Serbi Semiotika. Jakarta: Gramedia Pustaka Utama.

Website:

www.nbe.co.eg 